\title{
The role of endophytic methane-oxidizing bacteria in submerged Sphagnum in determining methane emissions of Northeastern Siberian tundra
}

\author{
F. J. W. Parmentier ${ }^{1,2}$, J. van Huissteden ${ }^{1}$, N. Kip ${ }^{3}$, H. J. M. Op den Camp ${ }^{3}$, M. S. M. Jetten ${ }^{3}$, T. C. Maximov ${ }^{4}$, and \\ A. J. Dolman ${ }^{1}$ \\ ${ }^{1}$ Department of Hydrology and Geo-environmental Sciences, Faculty of Earth and Life Sciences, VU University Amsterdam, \\ de Boelelaan 1085, $1081 \mathrm{HV}$, Amsterdam, The Netherlands \\ ${ }^{2}$ Division of Physical Geography and Ecosystems Analysis, Department of Earth and Ecosystem Sciences, Lund University, \\ Sölvegatan 12, 22362 Lund, Sweden \\ ${ }^{3}$ Department of Microbiology, Institute for Water and Wetland Research, Faculty of Sciences, Radboud University Nijmegen, \\ Heyendaalseweg 135, 6525 AJ, Nijmegen, The Netherlands \\ ${ }^{4}$ BioGeochemical Cycles of Permafrost Ecosystems Lab, Institute for Biological Problems of the Cryolithozone SB RAS, \\ Lenin ave. 41, 677980, Yakutsk, Russia
}

Received: 4 November 2010 - Published in Biogeosciences Discuss.: 24 November 2010

Revised: 29 April 2011 - Accepted: 9 May 2011 - Published: 24 May 2011

\begin{abstract}
The role of the microbial processes governing methane emissions from tundra ecosystems is receiving increasing attention. Recently, cooperation between methanotrophic bacteria and submerged Sphagnum was shown to reduce methane emissions but also to supply $\mathrm{CO}_{2}$ for photosynthesis for the plant. Although this process was shown to be important in the laboratory, the differences that exist in methane emissions from inundated vegetation types with or without Sphagnum in the field have not been linked to these bacteria before.

In this study, chamber flux measurements, an incubation study and a process model were used to investigate the drivers and controls on the relative difference in methane emissions between a submerged Sphagnum/sedge vegetation type and an inundated sedge vegetation type without Sphagnum. It was found that methane emissions in the Sphagnumdominated vegetation type were $50 \%$ lower than in the vegetation type without Sphagnum. A model sensitivity analysis showed that these differences could not sufficiently be explained by differences in methane production and plant transport.
\end{abstract}

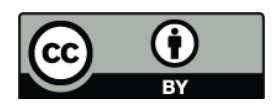

Correspondence to: F. J. W. Parmentier (frans-jan.parmentier@nateko.lu.se)
The model, combined with an incubation study, indicated that methane oxidation by endophytic bacteria, living in cooperation with submerged Sphagnum, plays a significant role in methane cycling at this site. This result is important for spatial upscaling as oxidation by these bacteria is likely involved in $15 \%$ of the net methane emissions at this tundra site. Our findings support the notion that methane-oxidizing bacteria are an important factor in understanding the processes behind methane emissions in tundra.

\section{Introduction}

Improved understanding of the controls and drivers of tundra methane emissions is important in the study of the global carbon cycle. While the cold tundra climate and the wet character of its soils have both led to a large buildup of carbon (Post et al., 1982; Tarnocai et al., 2009), these same wet soils are also a source of methane (Corradi et al., 2005; van der Molen et al., 2007; Wille et al., 2008), one of the most important greenhouse gases (Frolking et al., 2006). It has been hypothesized that these emissions might increase under a warmer climate (Zhuang et al., 2004; McGuire et al., 2009), and therefore an improved understanding of the biogeochemical functioning of tundra is needed to better appreciate its response to these changes.

Published by Copernicus Publications on behalf of the European Geosciences Union. 
Methane is formed by archaea below the water table, in the anoxic part of the soil as the final step in the series of processes that degrade organic matter (Whalen, 2005). The methane produced is then either emitted to the atmosphere or oxidized to $\mathrm{CO}_{2}$ above the water table in the aerated part of the soil by other microorganisms. The balance of production and oxidation therefore determines the amount of methane emitted by the ecosystem. For example, if the aerated part of the soil is deep enough, and the oxidation zone large, most or all of the methane can be consumed (Whalen and Reeburgh, 1990). On the other hand, methane emissions are at their highest when the water table is situated close to or at the surface.

In tundra, these wet areas tend to be dominated by sedges such as Eriophorum spp., Carex spp. and mosses such as Sphagnum spp. The vascular plants in this vegetation type further facilitate a release of methane through their aerenchyma that provide a direct pathway to the atmosphere, bypassing oxic zones in the soil where methane would normally be oxidized (Joabsson and Christensen, 2001; Greenup et al., 2000; Christensen et al., 2003; Ström et al., 2005). However, this plant structure also increases the transfer of oxygen into the soil, which can lead to significant oxidation of methane at the rhizosphere (Popp et al., 2000; Whalen, 2005). However, there have also been studies that show that little or no oxidation can occur in the sedges Eriophorum angustifolium and Eriophorum vaginatum (Frenzel and Rudolph, 1998). Furthermore, vegetation also influences the quality of substrate that is available for carbohydrate oxidation. Methane production is higher in the presence of more labile carbon than with dominantly stable organic matter, and it has been shown that sedges such as Eriophorum spp. provide fresh substrates through their roots, which is then converted into methane (Ström et al., 2005).

In contrast to the higher fluxes in the presence of vascular plants, it has been shown that methane emissions are lower in areas that have a Sphagnum cover (Hines et al., 2008). This has mostly been contributed to the low coverage of vascular plants in these areas, limiting plant transport of methane from the anoxic zone to the atmosphere. It has also been found that oxidation of methane is particularly high in Sphagnum (Vecherskaya et al., 1993; Sundh et al., 1995).

Recently it has been shown that oxidation in Sphagnum can also occur below the water table by a cooperation between methanotrophic bacteria and Sphagnum (Raghoebarsing et al., 2005). In this cooperation, the plant provides oxygen which allows the bacteria to oxidize methane into $\mathrm{CO}_{2}$, which is then returned to the plant to be used for photosynthesis. Furthermore, it has been shown that methane-derived carbon in Sphagnum can be as high as up to $35 \%$ (Kip et al., 2010), and this system could thus explain the high carbon burial found in Sphagnum peatlands. These methanotrophic endophytes are very common around the world (Kip et al., 2010), with varying rates of oxidation. However, there are very few studies that relate field observations of methane emissions from submerged Sphagnum to this specific type of bacteria since most studies on the spatial variations of methane fluxes focus on water level, NPP, vascular plant cover or oxidation in the aerated part of Sphagnum (Fechner and Hemond, 1992; Bubier, 1995; Frenzel and Rudolph, 1998; Greenup et al., 2000; Joabsson and Christensen, 2001; Christensen et al., 2003; Kutzbach et al., 2004; Basiliko et al., 2004; Ström et al., 2005; Minkkinen and Laine, 2006; Hines et al., 2008), while oxidation in inundated areas with Sphagnum vegetation is much less studied (Kip et al., 2010; Larmola et al., 2010; Liebner et al., 2011). Field studies in the Siberian Arctic are virtually not known due to logistical constraints. In this paper, we compare two inundated vegetation types in Northeastern Siberian tundra and show that methane emissions are significantly lower in a submerged Sphagnum/sedge vegetation type, in comparison to sedge vegetation with no Sphagnum presence, and ascertain that oxidation in submerged Sphagnum likely attributes to this difference.

\section{Materials and methods}

\subsection{Study site}

The study site is located in the nature reserve "Kytalyk" in Northeastern Siberia $\left(70^{\circ} 49^{\prime} 44.9^{\prime \prime} \mathrm{N}, 147^{\circ} 29^{\prime} 39.4^{\prime \prime} \mathrm{E}\right)$, about $30 \mathrm{~km}$ NW from the town of Chokurdakh in the Sakha Republic (Yakutia), Russian Federation (as shown in Fig. 1). While this location is extremely remote, only reachable by air during most of the year, and few carbon cycling studies have been performed previously in the region, this makes it an ideal and unique area for studying pristine and undisturbed tundra. The research area itself is situated in a former thermokarst lake that drained in the past when it was intersected to the south by the Berelekekh (Yelon) river, a tributary to the Indigirka river. The floodplain along the river and the former lakebed have different vegetation, soil and hydrology. Measurements in this research focus on the tundra terrace, in the former lakebed.

The climate is cold and continental with an average annual temperature of $-10.5^{\circ} \mathrm{C}$ and extremes as low as -25 to $-45^{\circ} \mathrm{C}$ in winter and 5 to $25^{\circ} \mathrm{C}$ in summer. Snowmelt usually occurs at the start of June, and while most snow is gone in mid June, bud break does not occur before the end of June or early July, together with the first warm days of the year. Since half way through September temperatures start to drop below zero again, the growing season is limited to the months of July and August. Summer temperatures are highly variable due to the large contrast between winds from the North and South. Northern winds blow cold air from the East Siberian sea (approx. $100 \mathrm{~km}$ away) while Southern winds bring hot summer air from the Siberian interior. This dependency on wind direction also means that the daily air temperature can drop by as much as $20^{\circ} \mathrm{C}$ in just two days 


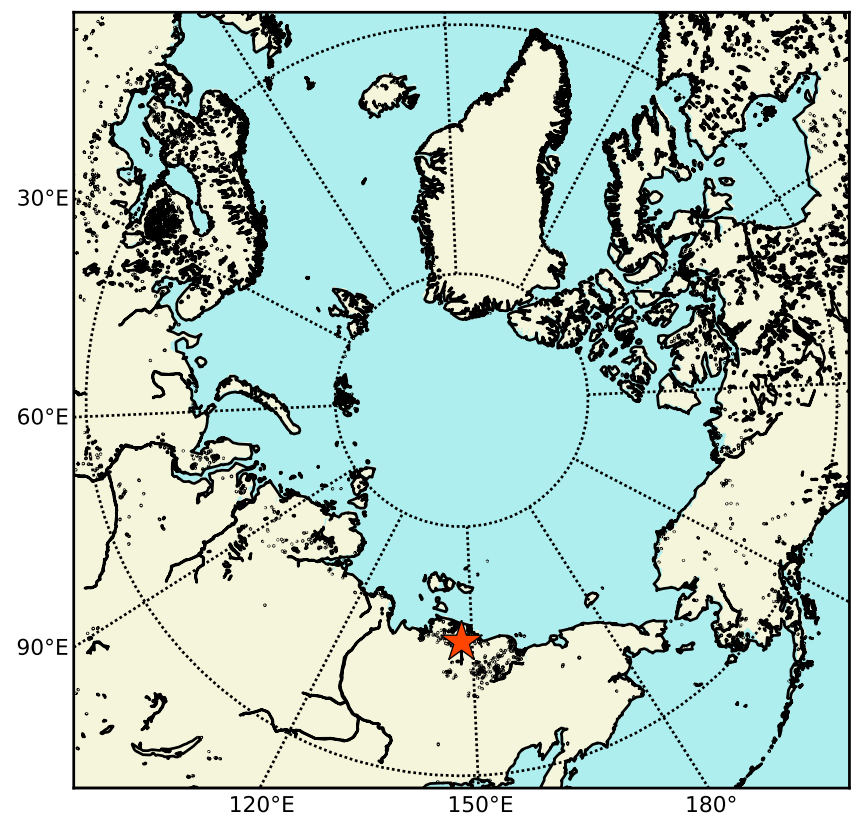

Fig. 1. Location of the research site within Northeastern Siberia.

if the wind direction changes from South to North. Since methane emissions are sensitive to temperature change, this also has an obvious effect on emissions on the short-term.

Annual precipitation is about 200 to $250 \mathrm{~mm}$ with approximately half of it falling as rain during the growing season. The other half falls in the rest of the year, mostly as snow. Although this amount of precipitation is similar to the yearly total in semi-arid areas, total evaporation is much lower, and thus the soil remains very wet and plenty of water is available for plant growth.

The vegetation is classified as graminoid tundra (tussocksedge, dwarf shrub, moss tundra, cf. circumpolar arctic vegetation map (Walker et al., 2005)). The spatial heterogeneity of the vegetation is related to the presence of ice-wedge polygon micro-topography leading to differences in soil water saturation. The higher and drier parts are dominated by either Betula nana and Salix pulchra dwarf shrubs with mosses or Eriophorum vaginatum hummocks interspersed with Salix pulchra dwarf shrubs and mosses. Towards the center of a polygon, soil conditions get wetter; Betula nana is no longer present and Salix pulchra cover gets more sparse while Sphagnum spp. cover increases and Carex aquatilis and Eriophorum angustifolium appear. Dominant Sphagnum species include $S$. balticum, S. compactum, S. subsecundum and $S$. squarrosum. The center, lowest parts of polygons are usually inundated and vegetation is dominated by Carex aquatilis and Eriophorum angustifolium while Sphagnum spp. cover is low or absent. Similar vegetation exists at the edges of ponds that are created by melting ice wedges, although transitions can be more abrupt. A more elaborate site description and comparison with other sites has previ- ously been given by van Huissteden et al. (2005) and van der Molen et al. (2007).

\subsection{Methane flux measurements}

To find areas that were suitable for comparison, the vegetation at the studied site was classified according to vegetation, geomorphology and water availability as described by van Huissteden et al. (2005). This classification identifies 12 different classes. Of these 12, the vegetation types TW1 and TW4, as described in Table 1, were used to compare between plots with and without Sphagnum. These vegetation types are responsible for almost all methane emissions of the tundra terrace and both are usually inundated, which means there is no aerated part of the soil or Sphagnum layer. TW1 is a vegetation type dominated by Eriophorum angustifolium and Carex aquatilis (typical cover of 40 to $95 \%$ ), where Sphagnum is mostly absent. TW4 is a vegetation type that is dominated by Sphagnum (cover of 50 to $100 \%$ ), but a substantial amount of vascular plants such as Carex aquatilis, Eriophorum angustifolium and Comarum palustre remains (typical cover of 20 to $30 \%$ ). This difference in vascular plant cover is possibly due to competition between Sphagnum and vascular plants, resulting in a lower cover of the latter (Heijmans et al., 2002).

The other ten classes were not considered here since they either referred to dry vegetation types with a water table below the surface or to areas with Sphagnum where the water table was below the top of the Sphagnum. Furthermore, the study of van Huissteden et al. (2005) also reported high methane emissions from the floodplain along the river but in this area no Sphagnum is present, and since hydrology, soil and vegetation are completely different from the tundra terrace, these vegetation types were not included in the comparison.

Measurements were performed on 5 plots of the TW1 vegetation type and 4 plots of the TW4 vegetation type, for which the spatial variation of vegetation within each class was taken into account visually. The plots were located in close vicinity to each other, often only separated by a few meters. Furthermore, only those measurement days were selected where both vegetation types were inundated, to avoid differences in the measured fluxes due to oxidation of methane in the aerated part of the soil or Sphagnum layer.

Chamber flux measurements were performed in the summer of 2007 between 18 July and 6 August with the use of an INNOVA 1412 Photoacoustic Field Gas-monitor (LumaSense Technologies A/S, Ballerup, Denmark), following the same measuring practice as described in van Huissteden et al. (2005). Each day the same 9 plots, situated along a boardwalk, were measured, to avoid the occurrence of variations in the measurements due to spatial differences. For each measurement point, a plastic collar of $30 \mathrm{~cm}$ in diameter and $10 \mathrm{~cm}$ in height was placed carefully in the top soil with a $14 \mathrm{dm}^{3}$ dark plastic chamber on top. A water lock 
Table 1. Description of the studied vegetation classes.

\begin{tabular}{llllll}
\hline Code & Site class & Soil & Water table & Vegetation & Vascular plant cover \\
\hline TW1 & $\begin{array}{l}\text { depression, diffuse } \\
\text { drainage }\end{array}$ & organic on mineral & $0-15 \mathrm{~cm}$ & $\begin{array}{l}\text { Eriophorum angustifolium, } \\
\text { Carex aquatilis }\end{array}$ & $40 \%$ to $90 \%$ \\
TW4 & $\begin{array}{l}\text { low polygon centre, } \\
\text { other depressions }\end{array}$ & organic & $0-10 \mathrm{~cm}$ & $\begin{array}{l}\text { Sphagnum, Eriophorum an- } \\
\text { gustifolium, Carex aquatilis, } \\
\text { Comarum palustre }\end{array}$ & $20 \%$ to $30 \%$ \\
\hline
\end{tabular}

was used in between the chamber and collar to prevent gas leakage. For $8 \mathrm{~min}$, methane concentrations were measured 5 times with a 2-min interval. The measurement was kept this short to make sure that the air in the chamber would not warm up too much, and this was further monitored with the use of a small thermometer inside the chamber. Also, the sampled air was first passed through a tube containing soda lime and a silica gel, which removed $\mathrm{CO}_{2}$ and reduced water vapor concentrations, to prevent cross-interference at high concentrations.

Fluxes were determined by linear interpolation of the measurements, accounting for air temperature, air pressure and, if there was standing water above the surface, also for reduced air volume in the chamber. Quality control was done by calculating the root mean square error (RMSE) of the linear regression. A high RMSE would occur in the case of a non-linear increase of concentration, in which case the measurement would have to be rejected, although this did not occur for the studied period and vegetation types. In some cases the total change in concentration would be very low $(<1 \mathrm{ppm})$ and erratic in behavior, due to the measurement accuracy of the device ( $0.4 \mathrm{ppm})$. In these cases, fluxes could not be determined accurately and because the possibility of some leakage cannot be excluded fully (although unlikely), these measurements were excluded to avoid biased means. Together with each flux measurement, the water table level, thickness of the active layer and soil temperatures at 0,10 and $20 \mathrm{~cm}$ were also measured.

\subsection{Incubation study}

In July 2008, two additional sites, NS1 and NS2, with a similar vegetation distribution as the TW4 flux sites, were selected for sampling Sphagnum. This sampling was done outside the measurement plots to avoid disturbance, allowing for future measurements in those plots. The samples were brought back to the Netherlands in closed plastic bags and kept cool as much as possible. During transits by airplane they were no longer than $20 \mathrm{~h}$ without active cooling. Incubation experiments were performed in September 2008. While flux measurements were performed in the previous year, van Huissteden et al. (2005) showed, by using a roving method throughout the studied area in the years preceding this study, that the difference between the studied vegetation types is quite similar between years.

Potential methane-oxidizing activity was measured by incubating whole Sphagnum plants, 20 grams of moist mass, in a $120 \mathrm{ml}$ serum bottle sealed with airtight grey butyl rubber stoppers and aluminum caps. Before incubation, the Sphagnum plants were thoroughly washed 3 times with sterile demineralized water. $1 \mathrm{ml}$ of methane (100\% pure, Air Liquide, the Netherlands) was added to each flask and the methane concentration in the flasks was measured on a HP 5890 gas chromatograph equipped with a flame ionization detector and a Porapak Q column (100/120 mesh). The methaneoxidizing activity test was performed in triplicate on ice and at 4,10 and $20^{\circ} \mathrm{C}$ in the dark. Following the incubations, the Sphagnum mosses were dried in a vacuum stove at $70^{\circ} \mathrm{C}$ to determine the dry weight.

Oxidation rates were determined at three separate stages. The initial methane oxidation rate, rate 1 , is measured between 0 and $18.5 \mathrm{~h}$, the second methane oxidation rate is determined between 20 and $46 \mathrm{~h}$, after adding new methane, and the last methane oxidation rate, rate 3 , is determined after $46 \mathrm{~h}$ when all the samples were incubated on ice. Since no peat bog water sample was available, the first wash water served as a control. Methane concentrations in the bottles were measured every hour or every day, depending on the activity, while methane oxidation rates were determined by regression analysis of the data points that showed a linear methane oxidation.

The obtained oxidation rates are determined in $\mu$ mol $\mathrm{CH}_{4} \mathrm{~g} \mathrm{DW}^{-1}$ day $^{-1}$, while fluxes in the field are measured in $\mathrm{mg} \mathrm{CH}_{4} \mathrm{~m}^{-2} \mathrm{~h}^{-1}$ and this makes it difficult to compare the two rates. Ideally, the two could be compared by multiplying with the amount of dry weight of Sphagnum per $\mathrm{m}^{2}$. However, oxidation rates from the incubation study were determined under ideal conditions with an ample supply of methane and oxygen which is unlikely to be the case for field conditions, and concentrations may vary vertically in the field. Nonetheless, by multiplying the incubation rates with the amount of dry weight of Sphagnum per $\mathrm{m}^{2}$, an indication will be given whether the optimal oxidation rates from the laboratory are in the same order of magnitude as in the field. If this arguably crude translation of fluxes from the laboratory to the field shows us lower rates than the observed 
differences, we know that these differences must be due to other factors than oxidation alone. Notably, the reverse does not necessarily hold true but provides a picture of potential oxidation under ideal circumstances.

To apply this crude method, four $0.25 \mathrm{~m}^{2}$ plots with the TW4 vegetation type were selected and all Sphagnum was collected. This Sphagnum was dried in an oven for a week at $60^{\circ} \mathrm{C}$ and weighed afterwards. This weight was used to calculate optimal oxidation rates in $\mathrm{mg} \mathrm{CH}_{4} \mathrm{~m}^{-2} \mathrm{~h}^{-1}$.

\subsection{Flux modeling}

While fast export of plant material allowed for an incubation study, the remote location of this research site and local legislative rules limited the possibilities for exporting soil samples or monoliths, performing isotope studies or inhibiting methane oxidation with $\mathrm{CH}_{2} \mathrm{~F}_{2}$. To overcome these limitations and to identify which parameters would best explain the differences observed, a process model was applied to model methane fluxes of both vegetation types. Methane fluxes from the Kytalyk site have been modeled by Petrescu et al. (2008) and van Huissteden et al. (2009) using the PEATLAND-VU model that includes a version of the Walter and Heimann (2000) wetland $\mathrm{CH}_{4}$ flux model (van Huissteden et al., 2006).

In this model, $\mathrm{CH}_{4}$ production below the water table linearly depends on labile organic $\mathrm{C}$ concentration with a production rate factor $R_{0}$. The labile $\mathrm{C}$ pool is produced by transfer of net primary production (NPP) into root exudates and plant litter. This depends on linear conversion factors for root-shoot and root-exudate allocation of $\operatorname{NPP}\left(f_{\text {shoots }}, f_{\text {ex }}\right)$, and the vertical root density distribution (exponential, determined by maximum root depth $Z_{\text {roots }}$ ). NPP depends on a maximum daily NPP, $P_{\max }$, which is scaled to soil temperature. Above the water table, $\mathrm{CH}_{4}$ is oxidized by methanotrophs, which depends on $\mathrm{CH}_{4}$ concentration and is modeled using a Michaelis-Menten relation. Soil-atmosphere transport includes diffusion, ebullition and transport by plants. Ebullition depends on a soil $\mathrm{CH}_{4}$ concentration threshold. Plant transport depends on soil $\mathrm{CH}_{4}$ concentration, root density, plant growth rate and a vegetation-dependent factor, $V_{\text {transp }}$. During transport part of the methane may be oxidized, which is modeled using a plant oxidation factor $f_{\text {ox }}$. This includes all plant-related oxidation (within the rhizosphere, in aerenchymous tissue and at the plant surface).

To show how sensitive the model was to each parameter, the GLUE method (General Likelihood Uncertainty Analysis, e.g. Beven, 2008) by van Huissteden et al. (2009) was applied. In the GLUE method, a large number of model runs are done with randomly selected values for the studied parameters. The results of each run are compared with measurement data and an objective function is calculated that indicates the model fit. Here, 2000 runs were used, which were compared with the measurement data for TW1 and TW4. The distribu- tion of objective function values vs. parameter values shows how sensitive the model performance is to different values for each parameter. We assume that a distinct clustering of high objection function values within a certain range of parameter values represents an approximation of the true values, given the model structure.

We used the Nash-Sutcliffe efficiency for grouped site data (Nash and Sutcliffe, 1970) which compares the model results with site group average and standard deviation. It is defined as

$\mathrm{NS}=1-\frac{\sigma_{\mathrm{e}}^{2}}{\sigma_{\mathrm{o}}^{2}}$

where $\sigma_{\mathrm{e}}^{2}$ is the error variance,

$\sigma_{\mathrm{e}}^{2}=\frac{1}{T-1} \sum_{t=1}^{T}\left(\hat{y}_{t}-y_{t}\right)$

in which $\hat{y}_{t}$ is the predicted value at time $t$, and $y_{t}$ the observed value, and $\sigma_{\mathrm{o}}^{2}$ the variance of the observations. NS has the value of 1 for a perfect fit, and values close to, or below 0 when the error variance is of the same magnitude or larger than the variance of the observations. In that case the model performs not better, or worse than a flux estimate simply based on the average of the data.

The GLUE analysis has been compared for both vegetation types. We compared all parameters that influence the methane flux, including methane production, the oxidation of methane during plant transport and plant transport rate (van Huissteden et al., 2009):

- $R_{0}$ : Methane production rate factor $\left(0.1-0.5 \mu \mathrm{Mh}^{-1}\right)$, relating the methane production rate to substrate quantity from plants.

- $f_{\mathrm{ox}}$ : (within plant) oxidation factor (0-1), reducing the amount of emitted $\mathrm{CH}_{4}$ from plants.

- $V_{\text {transp }}$ : plant transport factor (0-15), increasing the amount of emitted $\mathrm{CH}_{4}$ from plants.

- $f_{\text {shoots }}$ : fraction (0-1) of NPP allocated to aboveground shoots.

- $Z_{\text {roots }}:$ maximum root depth $(0.1-0.6 \mathrm{~m})$.

- $P_{\max }:$ maximum daily NPP $(0.001-0.005 \mathrm{~kg} \mathrm{C}$ $\mathrm{m}^{2}$ day $^{-1}$ ).

\section{Results}

\subsection{Methane flux measurements}

In Fig. 2, water level, active layer thickness and temperature for the two vegetation classes at each measurement day are shown. From the figure it becomes clear that soil temperature 

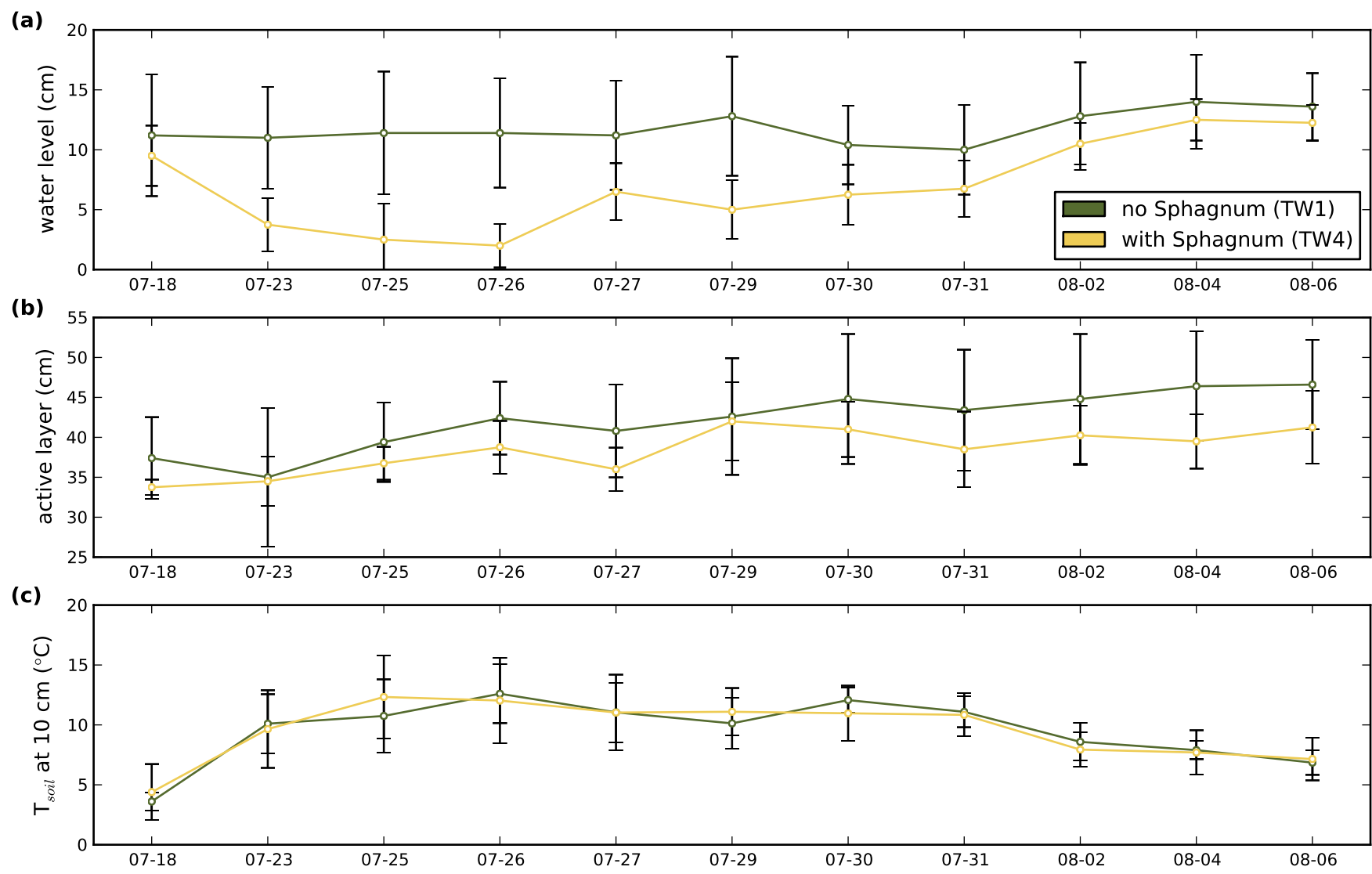

Fig. 2. Environmental parameters during the measurement campaign for the two vegetation types. Dark grey shows the data for the vegetation type without Sphagnum, TW1, while the data for the vegetation type with Sphagnum, TW4, is shown in light grey. Error bars denote standard deviations. (a) Daily water level above the surface. (b) Active layer thickness. (c) Daily soil temperature at $10 \mathrm{~cm}$ depth.

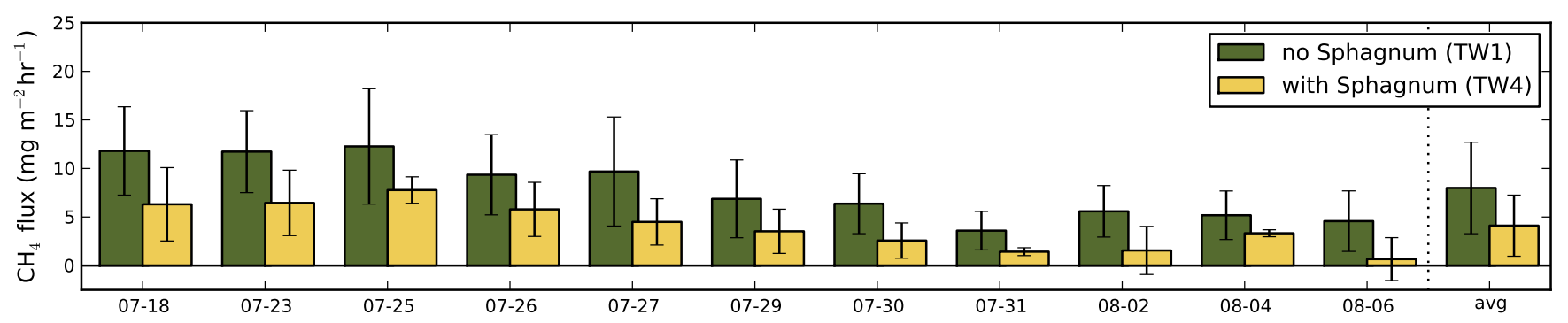

Fig. 3. Daily fluxes for terrain types without (TW1) and with Sphagnum (TW4). Measurements are shown per day and on the right the average flux of the two vegetation types is shown. Error bars denote the standard deviation of the measurements.

was very similar between the two vegetation types and active layer depth did not differ that much either. However, a significant difference was observed for water level. While water levels were above the surface for both vegetation types, the water level in TW4 was lower from 23 July to 30 July. After that, water levels were more similar, although a difference of 2 to $3 \mathrm{~cm}$ in water level remained.

In Fig. 3, the daily fluxes of the class with and without submerged Sphagnum have been plotted next to each other and the error bars represent the standard deviations of the measurements. Average daily fluxes ranged from 3.6 to $12.3 \mathrm{mg} \mathrm{CH}_{4} \mathrm{~m}^{-2} \mathrm{~h}^{-1}$ for TW1 and from 0.7 to $7.8 \mathrm{mg} \mathrm{CH}_{4}$ $\mathrm{m}^{-2} \mathrm{~h}^{-1}$ for TW4. The averages of all measured fluxes were $8.0 \pm 4.7 \mathrm{mg} \mathrm{CH}_{4} \mathrm{~m}^{-2} \mathrm{~h}^{-1}$ and $4.1 \pm 3.1 \mathrm{mg} \mathrm{CH}_{4} \mathrm{~m}^{-2} \mathrm{~h}^{-1}$ for TW1 and TW4, respectively. From the difference of the means it follows that the emissions from the vegetation type with submerged Sphagnum were half as much as emissions from the vegetation type without Sphagnum.

For each measurement day, the plots without Sphagnum show higher fluxes than the plots with Sphagnum, as 

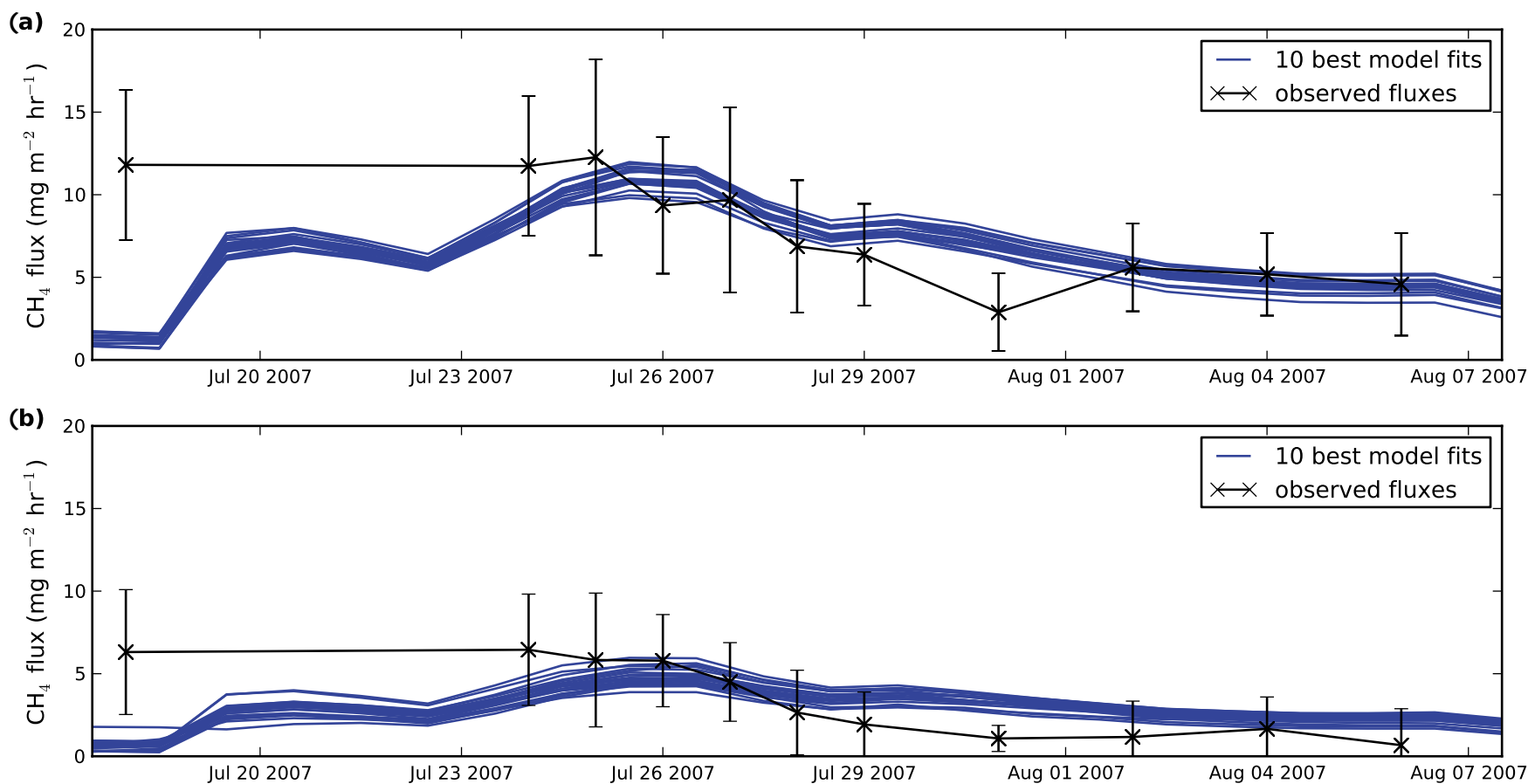

Fig. 4. The 10 best model fits (grey) plotted together with observed data (black). Error bars denote standard deviations.

Table 2. Mean methane oxidation rates for the two analyzed Sphagnum samples from sites NS1 and NS2 at different incubation temperatures. The values are in $\mu \mathrm{mol} \mathrm{CH}_{4} \mathrm{~g}^{-1}$ dry weight/day \pm standard deviation $(n=3)$.

\begin{tabular}{cccc}
\hline Temperature $\left({ }^{\circ} \mathrm{C}\right)$ & $4^{\circ}$ & $10^{\circ}$ & $20^{\circ}$ \\
\hline \multicolumn{4}{c}{ NS1 } \\
\hline Oxidation rate1 & $40 \pm 0.9$ & $58 \pm 0.5$ & $80 \pm 0.3$ \\
Oxidation rate2 & $30 \pm 0.7$ & $42 \pm 0.4$ & $75 \pm 0.6$ \\
\hline \multicolumn{4}{c}{ NS2 } \\
\hline Oxidation rate1 & $33 \pm 0.3$ & $39 \pm 0.4$ & $54 \pm 0.2$ \\
Oxidation rate2 & $32 \pm 0.6$ & $38 \pm 0.5$ & $62 \pm 0.5$ \\
\hline
\end{tabular}

expected. However, since the measurements were performed manually, only a limited amount of measurements (4 to 5) could be done per vegetation class per day. This led to a high standard deviation and there is some overlap between the two vegetation types. To show statistically that the two vegetation types do show different fluxes, a linear mixed model (Type III test of fixed effects with an AR(1) covariance structure, e.g. Littell et al., 1998) was performed with the use of PASW Statistics 18.0 (SPSS Inc., Chicago, IL). This method was preferred over a repeated measures ANOVA since the latter cannot handle missing data. The mixed model showed that the two vegetation types are indeed different at a $95 \%$ significancy level $(p=0.046)$.

\subsection{Incubation study}

High methane oxidation rates were found for the samples NS1 and NS2 at $4{ }^{\circ} \mathrm{C}, 10^{\circ} \mathrm{C}$ and $20^{\circ} \mathrm{C}$, as shown in Table 2 . Methane oxidation rates varied between 32 and $80 \mu$ mol $\mathrm{CH}_{4}$ $\mathrm{g} \mathrm{DW}^{-1}$ day $^{-1}$ and addition of new methane did not result in increased rates. Surprisingly, all samples showed activity between 2.7 and $7 \mu \mathrm{mol} \mathrm{CH}_{4} \mathrm{~g} \mathrm{DW}^{-1} \mathrm{day}^{-1}$, when incubations were continued on ice. Methane oxidation rates measured in the water controls were negligible since rates were $0.04 \pm$ $0.02 \mu \mathrm{mol} \mathrm{CH}_{4} \mathrm{~g} \mathrm{DW}^{-1}$ day $^{-1}$ on average. A more in-depth microbiological analysis on the bacterial community of these samples has been published previously by Kip et al. (2010).

The amount of dry weight of Sphagnum per $\mathrm{m}^{2}$ was determined to be $415 \pm 250 \mathrm{~g}$, which means that an oxidation rate from the incubation study of $10 \mu \mathrm{mol} \mathrm{CH}_{4} \mathrm{~g} \mathrm{DW}^{-1}$ day $^{-1}$ would equal $2.8 \pm 1.7 \mathrm{mg} \mathrm{CH}_{4} \mathrm{~m}^{-2} \mathrm{~h}^{-1}$ under idealized circumstances. The observed temperature range in the field was roughly between 4 and $12^{\circ} \mathrm{C}$ and, according to Table 2 , oxidation rates at these temperatures vary between 30 and $40 \mu \mathrm{mol} \mathrm{CH}_{4} \mathrm{~g} \mathrm{DW}^{-1} \mathrm{day}^{-1}$ or $8.4 \pm 5.0$ to $11.1 \pm 6.6 \mathrm{mg}$ $\mathrm{CH}_{4} \mathrm{~m}^{-2} \mathrm{~h}^{-1}$, which is about a factor of two larger than the observed difference between the two vegetation types. This large discrepancy between the field and the incubation study was expected, since these rates were determined under laboratory conditions, with ample $\mathrm{O}_{2}$ and $\mathrm{CH}_{4}$ available, and as such the two are not directly comparable. Nonetheless, these numbers indicate that a high potential for oxidation within Sphagnum exists. 

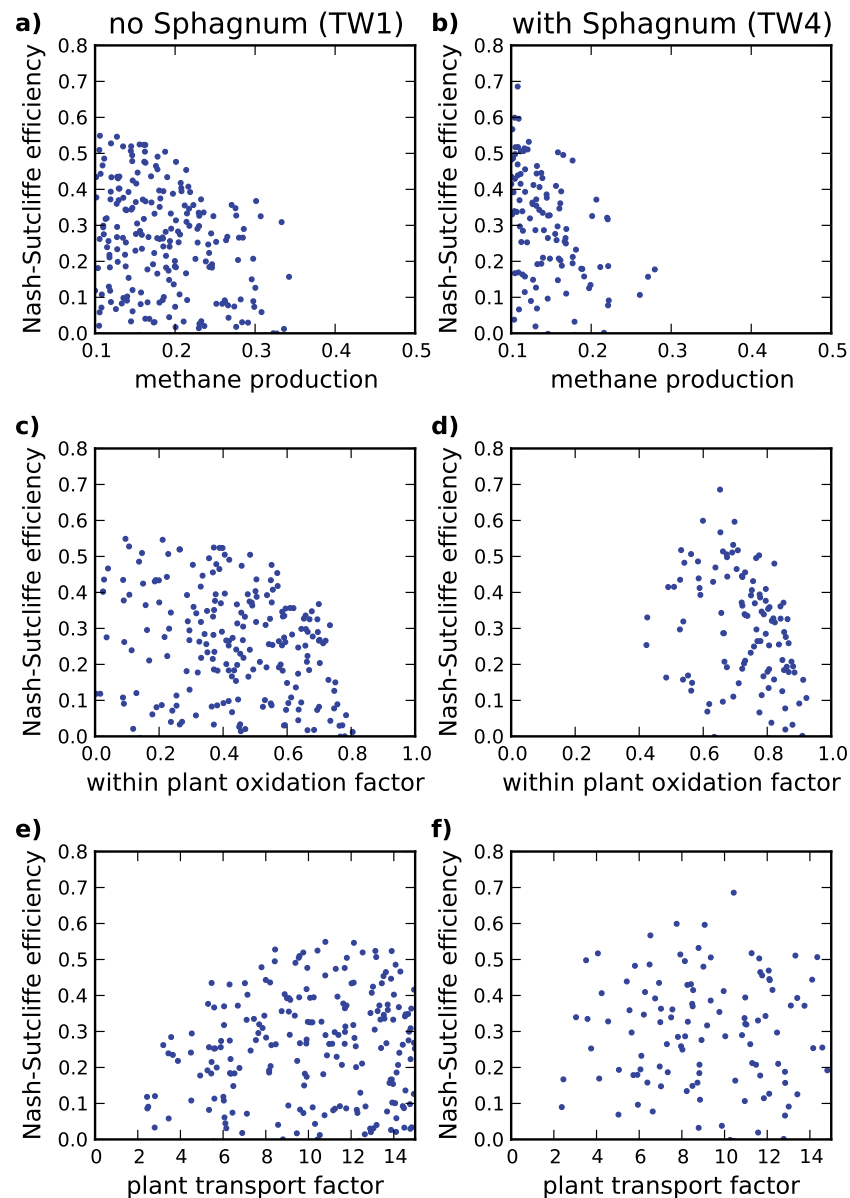

Fig. 5. GLUE analysis of model parameters for both vegetation types, showing Nash-Sutcliffe efficiency. On the left side (a, $\mathbf{c}$ and e) the results for the vegetation type without Sphagnum, TW1, are shown, while the results for the vegetation type with Sphagnum, TW4, are shown on the right hand side (b, $\mathbf{d}$ and $\mathbf{f})$. The top row (a and $\mathbf{b}$ ) shows values for methane production, $R_{0}$. The middle row (c and d) shows values for within plant oxidation of methane, $f_{\mathrm{ox}}$, and the bottom row (e and $\mathbf{f}$ ) shows values for plant transport factor, $V_{\text {transp. }}$

\subsection{Flux modeling}

The results of the model runs for the two vegetation types are shown in Fig. 4. For most days, the model agrees quite well, falling within the standard deviations of the observed values. Poor model performance only occurs on 18 July, when observed fluxes of sites without Sphagnum, TW1, are clearly higher than those modeled and on 31 July, when observed fluxes of both vegetation types are much lower than those modeled.

In Fig. 5, the results of the GLUE analysis are shown for all runs where the Nash-Sutcliffe efficiency was larger than zero and for the three parameters that are expected to influence methane emission most strongly, methane production, $R_{0}$, within plant oxidation, $f_{\mathrm{ox}}$, and plant transport, $V_{\text {transp }}$.
Of the 2000 random model runs, fewer runs gave a positive Nash-Sutcliffe efficiency for sites with Sphagnum than without Sphagnum and therefore fewer points are plotted for that vegetation type. The significance threshold $(p<0.1$, $\mathrm{NS}=0.551$ according to an F-test) was crossed for TW4 but not for TW1, but this is common for methane emission modeling (van Huissteden et al., 2009); for TW1 the threshold is approached.

More importantly, the GLUE results show large differences in the identifiability of the parameters. Likely values for $R_{0}$ ranged from 0.1 to $0.35 \mu \mathrm{Mh}^{-1}$ for TW1 and 0.1 to $0.3 \mu \mathrm{Mh}^{-1}$ for TW4. Values of $V_{\text {transp }}$ ranged from 2 to 15 for both vegetation types. Opposed to these largely overlapping ranges, $f_{\text {ox }}$ showed distinctively different ranges of 0 to 0.8 and 0.4 to 0.9 for TW1 and TW4, respectively. This clearer distinction for $f_{\text {ox }}$ becomes even more apparent when the average of these parameters is considered. Average values in TW1 and TW4 were 0.19 and $0.15 \mu \mathrm{M} \mathrm{h}^{-1}$ for $R_{0}$ $(p<0.001)$ and 10.1 and 9.0 for $V_{\text {transp }}(p<0.1)$, while $f_{\text {ox }}$ showed average values 0.44 and 0.73 , the latter value resulting in significantly higher oxidation (tested with t-test, $p<0.001)$. For the other parameters, no significant differences could be detected and are therefore not shown in Fig. 5.

It is likely that a difference in parameter identifiability and parameter values indicate realistic factors that influence the methane fluxes. This indicates that the difference in fluxes between the two vegetation types is best explained by differences in oxidation rate during transport, and to a lesser extent by differences in $\mathrm{CH}_{4}$ production rate and plant transport rate.

\section{Discussion}

The measurements of the methane emissions from the two inundated vegetation types show that fluxes from vegetation without submerged Sphagnum, TW1, was $8.0 \pm 4.7 \mathrm{mg} \mathrm{CH}_{4}$ $\mathrm{m}^{-2} \mathrm{~h}^{-1}$ and $4.1 \pm 3.1 \mathrm{mg} \mathrm{CH}_{4} \mathrm{~m}^{-2} \mathrm{~h}^{-1}$ for vegetation with submerged Sphagnum, TW4; a difference between the means of a factor of two. The standard deviation on the averages is quite large since the measured plots were selected in such a way that they represent the spatial variation for that vegetation type, and large variations between spatial replicates are therefore to be expected. In previous years however, the same difference between these two vegetation types was observed at the same site while using a roving measurement scheme for determining fluxes (van Huissteden et al., 2005, 2009; van der Molen et al., 2007), confirming these results. Furthermore, others have observed the high reduction in fluxes between these two types of vegetation as well, such as Hines et al. (2008), who similarly reported a $50 \%$ lower flux in a mixed vegetation of sedges and Sphagnum, compared to a sedge-only vegetation. 
Apart from the difference in fluxes, the two vegetation types observed also showed a large difference in vascular plant cover. Since this type of plant is able to influence methane emissions in wetlands (Joabsson et al., 1999), it would have been preferable to select sites where vascular plant cover was similar and only Sphagnum cover would be different. However, in the field it became clear that vascular plant cover was always higher for vegetation without Sphagnum, TW1, than for vegetation with Sphagnum, TW4. This difference in vascular plant cover could be due to competition between Sphagnum and vascular plants, as has been shown by Heijmans et al. (2002), making this difference a de facto situation that cannot be avoided, at least not in the field.

The question still remains whether the observed difference in fluxes can be attributed to vascular plant cover alone. To investigate this hypothesis, the average methane flux of all measurement sites was plotted against vascular plant cover, obtained from a vegetation mapping for each site, in Fig. 6. This figure shows that, as expected, the TW4 sites show lower fluxes and have a lower vascular plant cover than TW1. However, this difference in flux magnitude is not necessarily due to vascular plant cover. Alternatively, the difference in fluxes from the two classes could be explained by plotting them against Sphagnum cover, since TW4 has a high Sphagnum cover and TW1 none. Therefore, it was preferred to study the relationship between vascular plant cover and fluxes separately within each vegetation class. For each class, Fig. 6 clearly shows that there is no pattern with vascular plant cover and no significant regression could be found. Notably, the second highest fluxes in the TW1 class were measured in a plot with a vascular plant cover close to that of the TW4 plots.

The poor predictability of vascular plant cover on methane fluxes was confirmed by our modeling study. Average model parameters for within plant oxidation were $50 \%$ higher in areas with Sphagnum compared to areas without Sphagnum, while only a small difference was found in plant transport. So, although the two vegetation types have different vascular plant cover percentages, the measurements and model both suggest that vascular plant cover is not the most likely parameter to explain the observed differences.

When compared to previous research on plant transport (Joabsson and Christensen, 2001; Tsuyuzaki et al., 2001; Ström et al., 2003; Christensen et al., 2003; Kutzbach et al., 2004), this result seems counterintuitive, but it can be explained by the fact that vascular plants usually increase methane fluxes by bypassing the aerated parts of the soil where methane would otherwise be oxidized. In this study, no aerated soil layer, associated with methane oxidation, was present, since the studied vegetation types were always inundated. It is possible that this inundation reduced the difference between net transport to the atmosphere through aerenchyma and upward diffusion. As a result, the relative contribution of plant transport to net methane emissions would be smaller.

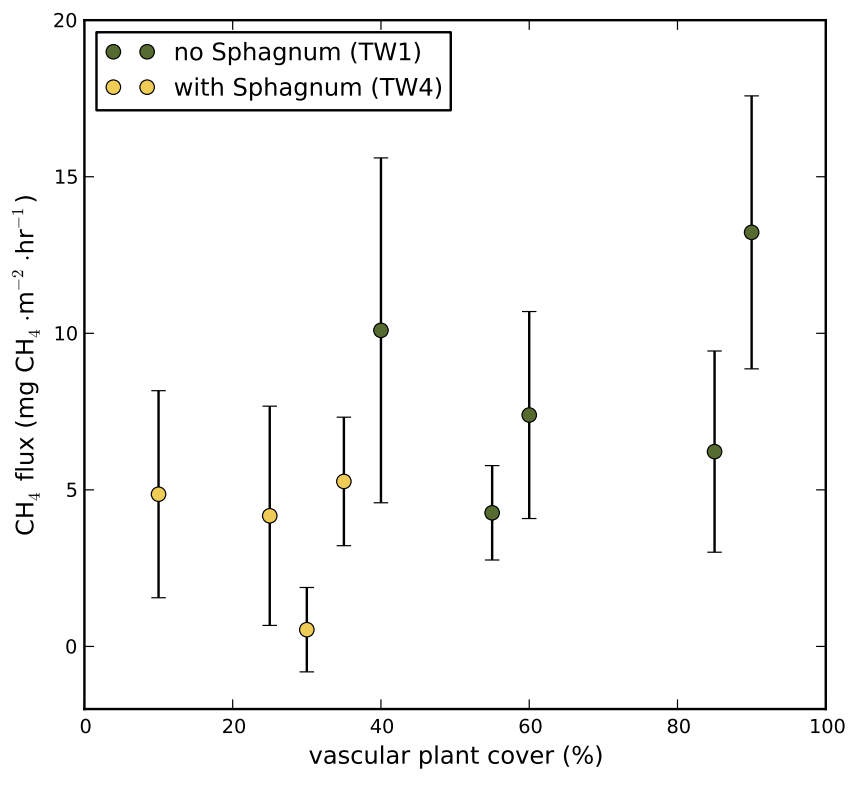

Fig. 6. Average methane fluxes of each measurement site, plot along its vascular plant cover. The error bars denote standard errors along all measurement days. Although there is a difference in vascular plant cover and methane flux between the two vegetation types TW1 and TW4, within each vegetation class there is no significant increase with vascular plant cover.

While this inundation reduced the relative influence of plant transport, it introduces a new issue since water levels were significantly different between vegetation types. Most measurements in July were performed with a higher water table for TW1 than for TW4, as shown in Fig. 2. Since this higher water table can lead to lower transport and higher oxidation of methane (Sachs et al., 2010), this could lead to differences in oxidation not related to the methanotrophic bacteria associated with Sphagnum. However, this potentially increased oxidation in TW1, the vegetation type without Sphagnum and exhibiting the highest emissions, would diminish both the absolute methane emissions from TW1 and the relative difference in emission between the two vegetation types, not increase them. Furthermore, the relative difference between the vegetation types shows no apparent effect of water table. While a large increase in the difference in water level between the vegetation types occurred between 18 July and 23 July, the relative difference in emissions did not change. Moreover, the largest relative difference in emissions between the vegetation types was observed for the last 4 measurement days when water levels in both vegetation types were very similar. The observed differences in fluxes are therefore not likely to be due to a difference in surface water level.

Although water column oxidation and plant transport were not likely to explain the differences observed, an alternative explanation to the higher emissions in TW1 than TW4 might lie in a difference in methane production. Methane 
production can be increased by the exudation of substrate by plants such as Eriophorum (Ström et al., 2005). While the amount of substrate and methanogenic activity in the soil could not be assessed due to legislative restrictions that preclude fast export of soil samples and limited analysis possibilities at the site, methane production related to substrate availability had to be modeled within the process model. In Fig. 5, it is shown that parameter values for methane production had quite similar ranges for both TW1 and TW4, with TW1 showing slightly higher possible values ( 0.3 vs. $0.35 \mu \mathrm{Mh}^{-1}$ ). Also, the average methane production for TW1 was $0.19 \mu \mathrm{M} \mathrm{h}^{-1}$ while TW4 had a somewhat lower average of $0.15 \mu \mathrm{Mh}^{-1}$. These results suggest that it's likely that production of methane was higher in TW1 but the difference between the two vegetation types is not very large and possible parameter values largely overlap. This would indicate that methane production can only partly explain the difference observed between the two vegetation types.

While the measurements and model indicate that the combination of plant transport, oxidation within the water column and methane production alone is not sufficient to explain the observed differences, the model did indicate that oxidation should be $50 \%$ higher in TW4 than TW1 to explain the observed differences. Indeed, the incubation study found very high methane oxidation rates in submerged Sphagnum. These high rates are not atypical when compared to oxidation rates for incubations of submerged Sphagnum samples from around the world. For example, a site from Argentina showed similar oxidation rates at $20^{\circ} \mathrm{C}$ (Kip et al., 2010). Most surprisingly, the samples from the studied site still showed some methane oxidation at $4{ }^{\circ} \mathrm{C}$ and on ice. No methane oxidation could be measured under those circumstances for the other samples incubated by Kip et al. (2010), who also showed, with the use of a methanotrophspecific methane mono-oxygenase gene (pmoA)-based PCR combined with a microarray (Bodrossy et al., 2003), and enrichment cultures, that this behavior is attributed to an unique methanotrophic bacterial community present in the Northeastern Siberian ecosystem. Apparently, this community is active over a very large temperature range, $0-20^{\circ} \mathrm{C}$, which explains why oxidation rates stay high in the cold Siberian soil.

The rates obtained from the incubation study were recalculated to fluxes per $\mathrm{m}^{2}$ by multiplying the oxidation rates by the amount of dry weight per $\mathrm{m}^{2}$. Although differences in methane and oxygen concentrations between the lab and the field preclude a direct comparison to differences observed in the field, they do show that there is a very high potential for methane oxidation in submerged Sphagnum if viewed under these ideal conditions. The conversion to $\mathrm{m}^{2}$ gave oxidation rates that were twice as high as in the field. This indicates that the potential for high oxidation in Sphagnum is there, although caution has to be expressed to view these numbers in an absolute way since they are most likely overestimating the real field conditions.
Thus, the results from the model and the incubation study both point towards high oxidation in the Sphagnumdominated vegetation type and it is less likely that the observed differences can be explained by methane production, within water column oxidation and plant transport alone. These observations make it likely that methanotrophic bacteria play a large role in the recycling of methane of the studied vegetation type.

\section{Conclusions}

In this study, methane emissions from two inundated vegetation types were compared. Areas dominated by submerged Sphagnum with some sedges were found to exhibit emissions that were two times lower than inundated vegetation dominated by sedges but without Sphagnum. An incubation study of submerged Sphagnum samples showed that very high oxidation rates of methane, even at $4{ }^{\circ} \mathrm{C}$ and on ice, were possible in this vegetation. This suggested that oxidation below the water table in submerged Sphagnum is one of the key processes in clarifying the difference between the two studied vegetation types.

To assess the likelihood in which other known parameters such as plant transport and methane production could explain the observed differences, both vegetation types were modeled in detail, together with a sensitivity analysis on the parameters. While this model study showed that methane production and plant transport might be somewhat higher in the vegetation type without Sphagnum, possible values largely overlapped and averages were comparable. Furthermore, the model appeared to be much more sensitive to within plant oxidation which showed average values that were $50 \%$ higher in the vegetation type with Sphagnum. This reaffirms the importance of the activity of these methanotrophic endophytes in submerged Sphagnum.

Since most methane at this tundra site is emitted from the two studied vegetation types, these results are also spatially important. Respective surface cover of the two vegetation types is 7 to 3 for TW1 and TW4 respectively (van der Molen et al., 2007), and this means that the vegetation type dominated by submerged Sphagnum represents $30 \%$ of the methane-emitting surface. If we assume a ratio of 2 to 1 in the emissions between the two vegetation types, it can be estimated that oxidation by methanotrophic endophytes is likely involved in $15 \%$ of the net methane emission from this tundra site.

We conclude, by combining flux chamber measurements, an incubation study and modeling, that this type of methanotrophic bacteria, that live in a cooperation with submerged Sphagnum, is an important factor in the recycling of methane within this tundra vegetation type. Although other factors such as methane production and plant transport are also important in determining emissions, the activity of these 
endophytic bacteria adds to a better understanding of the drivers and controls of methane emissions from tundra.

Acknowledgements. We like to acknowledge the people at the Institute for Biological Problems of the Cryolithozone SB RAS, Yakutsk for their assistance. In particular Alexander Kononov and Dimitri Suzdalov for all the help in the field in the summer of 2007 and Elena Ivanova and Lena Poryadina for the determination of the Sphagnum samples for the vegetation description. Furthermore we thank the people at the local WWF office in Chokurdakh who provided the logistical support and made it able for us to stay at the station throughout the season. Also, we like to thank Monique Heijmans for her helpful comments and Cinzia Berrittella for previous work on collecting and analyzing Sphagnum samples, which furthered interest to pursue this research. Finally, we like to thank the Darwin Center for Biogeosciences who supported this research with a grant to F. J. W. Parmentier (142.16.1041) and N. Kip (142.16.1061).

Edited by: C. P. Slomp

\section{References}

Basiliko, N., Knowles, R., and Moore, T. R.: Roles of moss species and habitat in methane consumption potential in a northern peatland, Wetlands, 24, 178-185, 2004.

Beven, K.: Environmental Modelling: An Uncertain Future?, Routledge: London, p. 328, 2008.

Bodrossy, L., Stralis-Pavese, N., Murrell, J., Radajewski, S., Weilharter, A., and Sessitsch, A.: Development and validation of a diagnostic microbial microarray for methanotrophs, Environm. Microbiol., 5, 566-582, 2003.

Bubier, J. L.: The relationship of vegetation to methane emission and hydrochemical gradients in northern peatlands, J. Ecol., 83, 403-420, 1995.

Christensen, T. R., Panikov, N. S., Mastepanov, M., Joabsson, A., Stewart, A., Oquist, M., Sommerkorn, M., Reynaud, S., and Svensson, B.: Biotic controls on $\mathrm{CO}_{2}$ and $\mathrm{CH}_{4}$ exchange in wetlands - a closed environment study, Biogeochemistry, 64, 337354, 2003.

Corradi, C., Kolle, O., Walter, K. M., Zimov, S. A., and Schulze, E.-D.: Carbon dioxide and methane exchange of a north-east Siberian tussock tundra, Global Change Biology, 11, 1910-1925, 2005.

Fechner, E. J. and Hemond, H. F.: Methane transport and oxidation in the unsaturated zone of a Sphagnum peatland, Global Biogeochem. Cycles, 6, 33-44, 1992.

Frenzel, P. and Rudolph, J.: Methane emission from a wetland plant: the role of $\mathrm{CH}_{4}$ oxidation in Eriophorum, Plant And Soil, 202, 27-32, 1998.

Frolking, S., Roulet, N. T., and Fuglestvedt, J.: How northern peatlands influence the Earth's radiative budget: Sustained methane emission versus sustained carbon sequestration, J. Geophys. Res.-Biogeosciences, 111, G01008, doi:10.1029/2005JG000091, 2006.

Greenup, A. L., Bradford, M. A., McNamara, N. P., Ineson, P., and Lee, J. A.: The role of Eriophorum vaginatum in $\mathrm{CH}_{4}$ flux from an ombrotrophic peatland, Plant And Soil, 227, 265-272, 2000.
Heijmans, M. P. D., Klees, H., and Berendse, F.: Competition between Sphagnum magellanicum and Eriophorum angustifolium as affected by raised $\mathrm{CO}_{2}$ and increased $\mathrm{N}$ deposition, Oikos, 97, 415-425, 2002.

Hines, M. E., Duddleston, K. N., Rooney-Varga, J. N., Fields, D., and Chanton, J. P.: Uncoupling of acetate degradation from methane formation in Alaskan wetlands: Connections to vegetation distribution, Global Biogeochem. Cycles, 22, GB2017, 2008.

Joabsson, A. and Christensen, T. R.: Methane emissions from wetlands and their relationship with vascular plants: an Arctic example, Global Change Biology, 7, 919-932, 2001.

Joabsson, A., Christensen, T. R., and Wallen, B.: Vascular plant controls on methane emissions from northern peatforming wetlands, Trends In Ecology \& Evolution, 14, 385-388, 1999.

Kip, N., van Winden, J. F., Pan, Y., Bodrossy, L., Reichart, G.J., Smolders, A. J. P., Jetten, M. S. M., Damste, J. S. S., and Op den Camp, H. J. M.: Global prevalence of methane oxidation by symbiotic bacteria in peat-moss ecosystems, Nature Geosci., 3, 617-621, 2010.

Kutzbach, L., Wagner, D., and Pfeiffer, E.-M.: Effect of microrelief and vegetation on methane emission from wet polygonal tundra, Lena Delta, Northern Siberia, Biogeochemistry, 69, 341-362, 2004.

Larmola, T., Tuittila, E.-S., Tiirola, M., Nykänen, H., Martikainen, P. J., Yrjälä, K., Tuomivirta, T., and Fritze, H.: The role of Sphagnum mosses in the methane cycling of a boreal mire, Ecology, 91, 2356-2365, 2010.

Liebner, S., Zeyer, J., Wagner, D., Schubert, C., Pfeiffer, E.-M., and Knoblauch, C.: Methane oxidation associated with submerged brown mosses reduces methane emissions from Siberian polygonal tundra, J. Ecol., 99, no, 2011.

Littell, R. C., Henry, P. R., and Ammerman, C. B.: Statistical analysis of repeated measures data using SAS procedures, J. Anim. Sci., 76, 1216-1231, 1998.

McGuire, A. D., Anderson, L. G., Christensen, T. R., Dallimore, S., Guo, L., Hayes, D. J., Heimann, M., Lorenson, T. D., Macdonald, R. W., and Roulet, N. T.: Sensitivity of the carbon cycle in the Arctic to climate change, Ecological Monographs, 79, 523555, 2009.

Minkkinen, K. and Laine, J.: Vegetation heterogeneity and ditches create spatial variability in methane fluxes from peatlands drained for forestry, Plant And Soil, 285, 289-304, 2006.

Nash, J. E. and Sutcliffe, J. V.: River flow forecasting through conceptual models part I - A discussion of principles, J. Hydrol., 10, 282-290, 1970.

Petrescu, A. M. R., van Huissteden, J., Jackowicz-Korczynski, M., Yurova, A., Christensen, T. R., Crill, P. M., Bäckstrand, K., and Maximov, T. C.: Modelling $\mathrm{CH}_{4}$ emissions from arctic wetlands: effects of hydrological parameterization, Biogeosciences, 5, 111-121, doi:10.5194/bg-5-111-2008, 2008.

Popp, T. J., Chanton, J. P., Whiting, G. J., and Grant, N.: Evaluation of methane oxidation in the rhizosphere of a Carex dominated fen in north central Alberta, Canada, Biogeochemistry, 51, 259-281, 2000.

Post, W. M., Emanuel, W. R., Zinke, P. J., and Stangenberger, A. G.: Soil carbon pools and world life zones, Nature, 298, 156-159, 1982.

Raghoebarsing, A. A., Smolders, A. J. P., Schmid, M. C., Rijp- 
stra, W. I. C., Wolters-Arts, M., Derksen, J., Jetten, M. S. M., Schouten, S., Damste, J. S. S., Lamers, L. P. M., Roelofs, J. G. M., Op den Camp, H. J. M., and Strous, M.: Methanotrophic symbionts provide carbon for photosynthesis in peat bogs, Nature, 436, 1153-1156, 2005.

Sachs, T., Giebels, M., Boike, J., and Kutzbach, L.: Environmental controls on $\mathrm{CH}_{4}$ emission from polygonal tundra on the microsite scale in the Lena river delta, Siberia, Global Change Biology, 16, 3096-3110, 2010.

Ström, L., Ekberg, A., Mastepanov, M., and Christensen, T. R.: The effect of vascular plants on carbon turnover and methane emissions from a tundra wetland, Global Change Biology, 9, 11851192, 2003.

Ström, L., Mastepanov, M., and Christensen, T. R.: Species-specific effects of vascular plants on carbon turnover and methane emissions from wetlands, Biogeochemistry, 75, 65-82, 2005.

Sundh, I., Mikkela, C., Nilsson, M., and Svensson, B. H.: Potential aerobic methane oxidation in a sphagnum-dominated peatland controlling factors and relation to methane emission, Soil Biology \& Biochemistry, 27, 829-837, 1995.

Tarnocai, C., Canadell, J. G., Schuur, E. A. G., Kuhry, P., Mazhitova, G., and Zimov, S. A.: Soil organic carbon pools in the northern circumpolar permafrost region, Global Biogeochem. Cycles, 23, GB2023, 2009.

Tsuyuzaki, S., Nakano, T., Kuniyoshi, S., and Fukuda, M.: Methane flux in grassy marshlands near Kolyma River, north-eastern Siberia, Soil Biology \& Biochemistry, 33, 1419-1423, 2001.

van der Molen, M. K., van Huissteden, J., Parmentier, F. J. W., Petrescu, A. M. R., Dolman, A. J., Maximov, T. C., Kononov, A. V., Karsanaev, S. V., and Suzdalov, D. A.: The growing season greenhouse gas balance of a continental tundra site in the Indigirka lowlands, NE Siberia, Biogeosciences, 4, 985-1003, doi:10.5194/bg-4-985-2007, 2007.

van Huissteden, J., Maximov, T. C., and Dolman, A. J.: High methane flux from an arctic floodplain (Indigirka lowlands, eastern Siberia), J. Geophys. Res.-Biogeosciences, 110, G02002, doi:10.1029/2005JG000010, 2005. van Huissteden, J., van den Bos, R., and Alvarez, I. M.: Modelling the effect of water-table management on $\mathrm{CO}_{2}$ and $\mathrm{CH}_{4}$ fluxes from peat soils, Netherlands J. Geosciences-Geologie En Mijnbouw, 85, 3-18, 2006.

van Huissteden, J., Petrescu, A. M. R., Hendriks, D. M. D., and Rebel, K. T.: Sensitivity analysis of a wetland methane emission model based on temperate and arctic wetland sites, Biogeosciences, 6, 3035-3051, doi:10.5194/bg-6-3035-2009, 2009..

Vecherskaya, M. S., Galchenko, V. F., Sokolova, E. N., and Samarkin, V. A.: Activity and species composition of aerobic methanotrophic communities in tundra soils, Current Microbiology, 27, 181-184, 1993.

Walker, D. A., Raynolds, M. K., Daniels, F. J. A., Einarsson, E., Elvebakk, A., Gould, W. A., Katenin, A. E., Kholod, S. S., Markon, C. J., Melnikov, E. S., Moskalenko, N. G., Talbot, S. S., and Yurtsev, B. A.: The Circumpolar Arctic vegetation map, J. Veg. Sci., 16, 267-282, 2005.

Walter, B. P. and Heimann, M.: A process-based, climate-sensitive model to derive methane emissions from natural wetlands: Application to five wetland sites, sensitivity to model parameters, and climate, Global Biogeochem. Cycles, 14, 745-765, 2000.

Whalen, S. C.: Biogeochemistry of methane exchange between natural wetlands and the atmosphere, Environ. Eng. Sci., 22, 73-94, 2005.

Whalen, S. C. and Reeburgh, W. S.: Consumption of atmospheric methane by tundra soils, Nature, 346, 160-162, 1990.

Wille, C., Kutzbach, L., Sachs, T., Wagner, D., and Pfeiffer, E.-M.: Methane emission from Siberian arctic polygonal tundra: eddy covariance measurements and modeling, Global Change Biol., 14, 1395-1408, 2008.

Zhuang, Q., Melillo, J. M., Kicklighter, D. W., Prinn, R. G., McGuire, A. D., Steudler, P. A., Felzer, B. S., and Hu, S.: Methane fluxes between terrestrial ecosystems and the atmosphere at northern high latitudes during the past century: A retrospective analysis with a process-based biogeochemistry model, Global Biogeochem. Cycles, 18, GB3010, doi:10.1029/2004GB002239, 2004. 